\title{
An investigation of the digital game addiction between high school students ${ }^{1}$
}

\author{
Nurullah Emir Ekinci \\ İlimdar Yalçın ${ }^{3}$ \\ Ömer Özer ${ }^{4}$ \\ Tayfun Kara ${ }^{5}$
}

\begin{abstract}
The aim of this study was to investigate the digital game addiction levels of the high school students, according to some variables such as sports participation, gender, place of accommodation and level of income.

The sample group comprises 931 high school students (508, \%54,6 female and 423, \%45,4 male) from several villages, districts and Kutahya city center (a town in the west part of Turkey with the population of 325.000). They participated to the study voluntarily. In addition to personal information from prepared by the researcher, the game addiction scale developed by Lemmens et al. (2009) and adapted to Turkish by Irmak and Erdogan (2015) was used as a data gathering tool. It is a five point Likert type scale and has one factor and seven items. In order to evaluate the results the descriptive statistical methods (percentage (\%), frequency (f) and t-test, one-way ANOVA) were used.

As a result, the significant difference was determined regarding digital game addiction $[\mathrm{t}(931)=-$ $3,76 ; \mathrm{p}=0,00]$ between the students who participate to the sports activities and who do not. So, the non-participant students found more game addicted. According to the gender, male students were determined more addicted than females [ $t(931)=9,45 ; \mathrm{p}=0,00]$. No significant difference was determined in terms of the place where the students lived $(p=0,56, p>0,05)$. Finally, the significant difference was determined in terms of the income levels, [ $\mathrm{f}(931)=3,07 ; \mathrm{p}=0,01]$ on behalf of the students who had good income level. They found more addicted.
\end{abstract}

Keywords: Digital game; Addiction; Sport; Youth.

${ }^{1}$ This study presented in International Scientific Conference "Sports, Education Culture-Interdisciplinary Approaches in Scientific Research, 26th-27th May 2017, Galati/ROMANIA.

${ }^{2}$ Assistant Professor, Mustaka Kemal University, Physical Education and Sport Department, ekinciemir@gmail.com

3Research Assistant, Sakarya University, Faculty of Sports Sciences, ilimdaryalcin@,sakarya.edu.tr

${ }^{4}$ Assistant Professor, Karamanoğlu Mehmet Bey University, Physical Education and Sport Department, besyo4307@gmail.com

${ }^{5}$ Lecturer, Istanbul Gelisim University/ Istanbul Gelişim Vocational School/Sports Management, takara@gelisim.edu.tr 
Ekinci, N. E.., Yalçın, İ., Özer, Ö., \& Kara, T. (2017). An investigation of the digital game addiction between high school students. Journal of Human Sciences, 14(4), 4989-4994. doi:10.14687/jhs.v14i4.4936

\section{Introduction}

Internet addiction disorder (IAD) defined as "one's inability to control internet using, which could lead to physical, psychological, and social difficulties." Particularly addictions on the internet are online gaming, social networking and online shopping (Khan et al. 2017). In the recent years, researches have been conducted to answer the question "whether technological addictions such as internet addiction, social media addiction, digital game addiction and smartphone addiction are myths or are they behavioral addictions?" (Savc1 and Aysan, 2017). According to Holden (2001) most researchers define that technology addiction is a particular type of behavioral addiction. Recently a important increase in the number of empirical studies investigating diverse perspectives of problematic video game addiction and video game play (Griffiths et al. 2012). This topic became very valuable because internet usage has grow plosively, with more than 3.5 billion users worldwide (Khan et al. 2017). Because digital games (video games or computer games) are positively admited among teenagers and children (Zin et al. 2009). Especially in the United States, video game industry touches yearly earnings of 15 billion, the majority is between 14-19 years old (Annetta \& Cheng, 2008).

This topic is important for children and teenagers because games brought some adverse effects. "In the modern lifestyle where technology with the inclusion of internet has facilitated man, it can be a possible cause of decreased physical activity" (Cheng \& Li, 2014). Digital games can cause a tremendous amount of consequences to the player (Young, 2009; Block, 2008; Seok and DaCosta 2014; Griffiths, 2008). Also, Caplan (2002), suggested that unhealthy technology overuse can be problematic and may have negative consequences.

The most dangerous consequence is a loss of control: unable to limit time or resources spent on the activity (Ahrends, 2017). And also it cause some other problems like; low selfesteem, high levels of timidness and loneliness (Julia et al. 2014), heart rate increase (Griffiths and Dancaster, 1995), well-being (Demirci et al. 2015), sleep quality (Espinoza \& Juvonen 2011), aggressiveness and impulsivity (Wo, 2003), academic performance (Brunborg et al. 2014; Skoric et al. 2009), social life and emotional functioning (Turel et al. 2011) psychological issues; depression, compulsion, suicidal tendencies, attention shortfall as well as hyperactivity (Julia et al. 2014) and low self-admission (Montag et al. 2011) positively associated with problematic gaming propensities. According to Wood et al. (2007), the common outcome is time lost, and spending too much time on one activity can compose its problems.

According to Savc1 and Aysan (2017) internet is a source for addiction. Therefore, concepts such as digital game addiction, smartphone addiction and social media addiction can be considered as addictions in which the active substance is the internet. In the literature, there is some reason for gamers why they spent much time for games and became addicted. According to Wood et al. (2007), "high-frequency video game players were far more likely than low-frequency players to play games to escape from other problems" (social, economic, educational etc.) in their lives. According to Kuss et al. (2012), "games offer unique coping strategies to turn users' attention and energy away from real life problems and stress". According to Park et al. (2016), "sports has a positive effect on self-control and the effect of self-control on internet addiction".

So, in this regard, we try to find game addiction level of high school students and the way which causes students to become addicted and the way which can protect them from that habit. In particular, this study had three objectives: (1) to see effect of sports; (2) effect of money; and (3) effect of growing area on students.

\section{Material and Method}

\subsection{Study Design}

In the study, a cross-sectional analytical method used as study design, and according to Gratton and Jones (2010) this method is perhaps the most commonly used method in social and 
Ekinci, N. E.., Yalçın, İ., Özer, Ö., \& Kara, T. (2017). An investigation of the digital game addiction between high school students. Journal of Human Sciences, 14(4), 4989-4994. doi:10.14687/jhs.v14i4.4936

sport based studies. According to this method, the data obtained from a sampling group relationship is identified and generalized back to the population.

\subsection{The Research Group}

A total of 961 randomly chosen high school students from several villages, districts and Kutahya city center (a town in the west part of Turkey with the population of 325.000) participated to the study voluntarily but, 30 students were eliminated. So, the sampling group comprised of 931 primary and high school students ( $\mathrm{N}=508$ female, $\mathrm{N}=423$ male) who have been using the Internet, playing digital games, and using social media for at least one year, and have at least one social media account and a smartphone. The age range was from 14 to 19 years $(\mathrm{M}=16.42, \mathrm{SD}=1.17)$.

\subsection{Data Collection Tools}

In the research, the game addiction scale developed by Lemmens et al. (2009) and adapted to Turkish by Irmak and Erdogan (2015) was used as a data gathering tool. The DGAS- It is a five point Likert type scale and has one factor and seven items. The Content Validity Index for the DGAS-7 was 0.92, Cronbach's alpha coefficient of the DGAS-7 was 0.72 , and item-total correlation ranged between 0.52 and 0.76 . There are no reverse-scored items, and high scores indicate increased the risk of digital game addiction (Yalcin Irmak \& Erdogan 2015).

\subsection{The Data Analysis}

In this context, firstly data set was examined regarding loss and extreme values. Missing data replaced with series mean. Then extreme values were analyzed and no extreme data which could adversely affect the analysis. After outlier analyses 30 answers eliminated. Also, skewness and kurtosis values evaluated skewness or kurtosis variables were within acceptable values for the research between +2 and -2 (George \& Mallery, 2010). The reliability of the scale assessed via Cronbach's alpha method and Cronbach's alpha calculated as 0.73 . Lastly, the data of the research were analyzed by parametric statistical methods (t-test and one-way ANOVA test procedure used). The margin of error in the study was taken as $\mathrm{p}<0.05$. Data were analyzed using Statistical Package for the Social Sciences (SPSS) version 21.

\subsection{Assumptions}

1. It is assumed that the method applied in this study is appropriate.

2. The selected sample of the group is assumed to represent the population of the study.

3. It is assumed that the answers given by the students in this study to the data collection tools are given in accordance with the sincere and facts.

\section{Findings}

In this section, the findings regarding the variables of our study are given. The findings which demonstrate the distributions of the participants with regard to their personal information were analyzed and interpreted.

Table 1: T-test Results for Gender

\begin{tabular}{lcccccc}
\multirow{2}{*}{ Digital Game Addiction } & Gender & $\mathbf{N}$ & $\bar{X}$ & Sd & t & p \\
\cline { 2 - 5 } & Female & 508 & 12,57 & 1,71 & \multirow{2}{*}{9,45} & \multirow{2}{*}{0,00} \\
\cline { 2 - 5 } & Male & 423 & 11,39 & 2,12 & & \\
\hline
\end{tabular}

According to gender difference and game addiction statistically, a significant result was found between male and females $(p<0.05)$. 
Ekinci, N. E.., Yalçın, İ., Özer, Ö., \& Kara, T. (2017). An investigation of the digital game addiction between high school students. Journal of Human Sciences, 14(4), 4989-4994. doi:10.14687/jhs.v14i4.4936

Table 2: T-test Results for Sport Participation

\section{Digital Game Addiction}

\begin{tabular}{cccccc} 
Sportive Activity & $\mathbf{N}$ & $\overline{\mathrm{X}}$ & $\mathbf{S d}$ & $\mathbf{t}$ & $\mathbf{p}$ \\
\cline { 1 - 5 } Yes & 621 & 12,83 & 5,34 & \multirow{2}{*}{$-3,76$} & \multirow{2}{*}{0,00} \\
\cline { 1 - 6 } & 310 & 14,30 & 6,19 & & \\
\hline
\end{tabular}

According to participants sportive activity level and game addiction statistically a significant result was found between students' who participate sportive activities and who do not participate sportive activities $(\mathrm{p}<0.05)$.

Table 3: Anova- test Results for Income Level

\begin{tabular}{|c|c|c|c|c|c|c|c|}
\hline \multirow{7}{*}{$\begin{array}{l}\text { Digital Game } \\
\text { Addiction }\end{array}$} & Income & $\mathbf{N}$ & $\overline{\bar{X}}$ & Sd & $\mathbf{F}$ & $p$ & Tukey \\
\hline & Very bad & 51 & 11,60 & 1,98 & \multirow{6}{*}{3,07} & \multirow{6}{*}{0,01} & \multirow{6}{*}{$2-4 *$} \\
\hline & $\mathrm{Bad}$ & 77 & 11,44 & 2,32 & & & \\
\hline & Normal & 420 & 12,09 & 1,98 & & & \\
\hline & Good & 278 & 12,22 & 1,88 & & & \\
\hline & Very good & 105 & 11,96 & 2,03 & & & \\
\hline & Total & 931 & 12,03 & 1,99 & & & \\
\hline
\end{tabular}

According to participants income level and game addiction statistically, a significant result was found between students' who have a bad income level and student who has a good income level $(\mathrm{p}<0.05)$.

Table 4: Anova-test Results for Accommodation Place

\begin{tabular}{|c|c|c|c|c|c|c|c|}
\hline \multirow{5}{*}{$\begin{array}{c}\text { Digital Game } \\
\text { Addiction }\end{array}$} & Accommodation & $\mathbf{N}$ & $\overline{\bar{X}}$ & Sd & $\mathbf{F}$ & $\mathrm{p}$ & Tukey \\
\hline & Village & 230 & 12,13 & 1,87 & \multirow{4}{*}{0,56} & \multirow{4}{*}{0,56} & \multirow{4}{*}{----- } \\
\hline & District & 286 & 12,06 & 2,04 & & & \\
\hline & City & 415 & 11,96 & 2,03 & & & \\
\hline & Total & 931 & 12,03 & 1,99 & & & \\
\hline
\end{tabular}

According to participant accommodation place statistically, there was not a significant result between students who grow up in a village, district or city $(\mathrm{p}>0,05)$.

\section{Discussion and Conclusion}

This paper has tried to examine the relationship between game addiction, gender, regular sports participation, income level and accommodation place. T-test analyze results showed that the relationship between gender $(p=0,00 ; p<0,05)$ and sport participation $(p=0,00 ; p<0,05)$ game addiction was found to be significant. According to these results, we can say those female students are more addicted than male students. This result can be because of the different life style between village and city center. In village mostly male works and females stay at home and also there are many activities which male can participate but in the city center male and female has mostly the same conditions. When we examine the literature, studies mostly show that male students dedicate more time than females to playing digital games (Bonanno and Kommers 2005). Phillips et al. (2005) found males four times more addicted than females. Ricardo \& Rosa (2002) found males were significantly more likely to play regularly than females. But according to the study of Kim et al. (2008) about the online game addiction and some personality traits, there weren't any significant differences between males and females game addiction. This study also showed the positive effect of sport on students who attend sportive activities. Students who attend sports activities were found to be less addicted to the digital games. When people participate in sportive activities this activities take some time and after activities body requires rest. This process can keep the students far from the digital games. In the literature there are some studies improved the positive effect of sport on game addiction. According to Kim (2016), sport as a moderating factor was significant in computer game addiction. Ekinci et al. (2016), mentioned a positive relationship between regular sports participation and game addiction. According to the study of Khan et al. (2017), "total score 
Ekinci, N. E.., Yalçın, İ., Özer, Ö., \& Kara, T. (2017). An investigation of the digital game addiction between high school students. Journal of Human Sciences, 14(4), 4989-4994. doi:10.14687/jhs.v14i4.4936

and frequency of internet addiction were higher in students lacking physical activity as compared to those with regular physical activity". According to Danish et al. (1995) and Pitter \& Andrews (1997), sports activities have regarded as a handy tool to prevent a variety of social issues.

Anova test results for income level showed a significant relationship between addiction and income level of students $(\mathrm{p}=, 01 ; \mathrm{p}<0,05)$ the significant differences was between bad income level and good income level according to this result we can say students who have a good income level has more opportunity to reach digital tools. Anova test results for accommodation place showed that there is not a significant difference between accommodation places of the students. According to this result, we can say nowadays it is effortless to reach digital tools no matter where they leave.

\subsection{Limitations and Future Studies}

Although this study revealed significantly meaning results about addiction level of adolescent, it is impossible to assess general addiction information in a single study. The limitations of our study: first, all the participants were from the same city and limited with one type high school that's why they may have the same behavior attitudes. Second, other personal factors such as academic performance or environmental conditions may affect their addiction level. For future studies, it will help to get better information about adolescent addiction level with larger sampling groups and independent variables. Also, it is crucial to prove the connection between game addiction and leisure time spending habits of the adolescent.

\section{References}

Ahrends, C. (2017). Does Excessive Music Practicing Have Addiction

Potential?. Psychomusicology, 27(3), 191.

Annetta, L.A. \& Cheng, M.T. (2008). Why educational video games? Serious educational games: from theory to practice, Sense Publishers, Rotterdam.

Block, J. J. (2008). Issues for DSM-V: Internet Addiction. American Journal of Psychiatry (165:3), pp. 306-307.

Bonannoa, P. \& Kommers, P. A. M. (2005). Gender differences and styles in the use of digital games. Educational Psychology, 25 (1), 13-41.

Brunborg, G. S., Mentzoni, R. A. \& Frøyland, L. R. (2014). Is video gaming, or video game addiction, associated with depression, academic achievement, heavy episodic drinking, or conduct problems?. Journal of behavioral addictions, 3(1), 27-32.

Caplan, S. E. (2002). Problematic Internet Use and Psychosocial Well-Being: Development of a Theory-Based Cognitive-Behavioral Measurement Instrument. Computers in Human Behavior (18:5), pp. 553-575.

Cheng, C. \& L, A. Y. L. (2014). Internet addiction prevalence and quality of (real) life: a metaanalysis of 31 nations across seven world regions. Cyberpsychology, Behavior, and Social Networking, 17(12), 755-760.

Danish, S. J., Petitpas A. \& Hale, B. D. (1995). "Psychological interventions: A life development model," Murphy, S. M. (Eds.), Sport psychology interventions, Champaign, IL: Human Kinetics, pp. 19- 38.

Demirci, K., Akgönül, M. \& Akpinar, A. (2015). Relationship of smartphone use severity with sleep quality, depression, and anxiety in university students. Journal of behavioral addictions, 4(2), 85-92.

Ekinci, N.E. Ustun, U.D. \& Ozer, O. (2016). An Investigation of the Relationship between Digital Game Addiction, Gender and Regular Sport Participation. Journal of education culture and Society No:2 pp. 298-303.

Espinoza, G. \& Juvonen, J. (2011). The pervasiveness, connectedness, and intrusiveness of social network site use among young adolescents. Cyberpsychology, Behavior, and Social Networking, 14(12), 705-709. 
Ekinci, N. E.., Yalçın, İ., Özer, Ö., \& Kara, T. (2017). An investigation of the digital game addiction between high school students. Journal of Human Sciences, 14(4), 4989-4994. doi:10.14687/jhs.v14i4.4936

George, D., \& Mallery, M. (2010). SPSS for Windows Step by Step: A Simple Guide and Reference, 17.0 update (10a ed.) Boston: Pearson.

Gratton, C. \& Jones, I. (2010). Research Methods for Sports Studies. 2nd Edition, London: Routledge.

Griffiths, M. D., Kuss, D. J. \& King, D. L. (2012). Video Game Addiction: The Past, Present, and Future, Current Psychiatry Reviews, Vol. 8, No. 4

Griffiths, M.D. \& Dancaster, I. (1995). The effect of type a personality on physiological arousal while playing computer games, Addictive Behaviors, 20 (4), 543-548.

Holden, C. (2001). 'Behavioral'addictions: do they exist?. Science, 294(5544), 980-982.

Julia K., Diana R., James D. Ivory \& Christopher F. (2014). Awareness of Risk Factors for Digital Game Addiction: Interviewing Players and Counselors. International Journal Mental Health Addiction, 12:585-599, DOI 10.1007/s11469-014-9489-y.

Khan M.A., Shabbir F. \& Rajput T.A. (2017). Effect of Gender and Physical Activity on Internet Addiction in Medical Students. Pak J Med Sci. 33(1):191-194. doi: https://doi.org/10.12669/pjms.331.11222.

Kim, E.J., Namkoong, K., Ku, T. And Kim, S.J. (2008). The relationship between online game addiction and aggression, self-control, and narcissistic personality traits, science direct. European psychiatry, 23; 212-218.

Kim, N. S. (2016). Effects of Sport for Preventing Violence and Computer Game Addiction in Youth. International Journal of u-and e-Service, Science and Technology, 9(4), 279-284.

Kuss, D. J., Louws, J. \&Wiers, R.W. (2012). Online gaming addiction? Motives predict addictive play behavior in Massively Multiplayer Online Role-playing games. Cyber psychology, Behavior and Social Networking, 15(9), 480-485. doi:10.1089/cyber.2012.0034.

Lemmens, J. S. \& Valkenburg, P. M. Peter, J. (2009). Development and validation of a game addiction scale for adolescents. Media Psychology, 12 (Suppl.1): 77-95.

Montag, C., Flierl, M., Markett, S., Walter, N., Jurkiewicz, M. \& Reuter, M. (2011). Internet addiction and personality in First-Person-Shooter video gamers. Journal of Media Psychology: Theories, Methods, and Applications, 23(4), 163-173. doi:10.1027/1864-1105/a000049.

Park, J.A., Park, M.H., Shin, J.H Li, B., Rolfe, D.T., Yoo, J.Y., Ditmore, W.D. (2016). Effect of sports participation on Internet addiction mediated by self-control: A case of Korean adolescents. Kasetsart Journal of Social Sciences, 37 (3), pp. 164-169.

Savcı, M., \& Aysan, F. (2017). Teknolojik Bağımllıklar ve Sosyal Bağlılık: İnternet Bağımlılığı, Sosyal Medya Bağımlllığı, Dijital Oyun Bağımlllığı ve Akıllı Telefon Bağımlılığının Sosyal Bağlllı̆̆1 Yordayıc1 Etkisi. Dusunen Adam, 30(3), 202-216.

Seok, S., \& DaCosta, B. (2014). An Investigation into the Questionable Practice of Using Excessive Massively Multiplayer Online Game Play as a Marker of Pathological Video Game Dependence among Adolescent and Young Adult Male Players Soonhwa. Psychology, 5(4), 289-299.

Skoric, M. M., Teo, L. L. C. \& Neo, R. L. (2009). Children and video games: Addiction, engagement and scholastic achievement. Cyberpsychology \& Behavior, 12:567-572.

Turel O., Serenko A. \& Giles P. (2011). Integrating technology addiction and use: an empirical investigation of online auction users. MIS Quart. 35 1043-1061

Wood, R. T. A., Griffiths, M. D. \& Parke, A. (2007). Experiences of time loss among videogame players: An empirical study. Cyberpsychology and Behavior, 10(1), 38-44.

Yalçın Irmak, A. \& Erdoğan, S. (2015). Dijital Oyun Bağımlılı̆̆1 Ölçeği Türkçe formunun geçerliliği ve güvenilirliği. [Validity and reliability of the Turkish version of the digital game addiction scale. In Turkish]. Anadolu Psikiyatri Dergisi, 16 (Special Issue 1), pp.10-18, Doi: 10.5455/Apd.170337.

Zin, N. A. M., Jaafar, A. \& Yue, W. S. (2009). Digital game-based learning (DGBL) model and development methodology for teaching history. WSEAS transactions on computers, 8(2), 322333. 